\title{
A New Biomarker for Hepatocellular Damage: Plasma Cell-Free DNA*
}

\author{
Zhi Yan ${ }^{1}$, Yingli $\mathrm{He}^{1}$, Qian $\mathrm{Li}^{1}$, Meiling Cui ${ }^{1}$, Ke Wang ${ }^{1}$, Tianyan Chen ${ }^{2}$, Hongli Liu ${ }^{2}$, \\ Ying-Ren Zhao ${ }^{2 \#}$ \\ ${ }^{1}$ Department of Infectious Diseases, The First Affiliated Hospital of Medical College, Xi' an Jiaotong University, \\ Xi'an, China \\ ${ }^{2}$ Hepatology Institution, The First Affiliated Hospital of Medical College, Xi'an Jiaotong University, \\ Xi'an, China \\ Email: " zhaoyingren@sohu.com
}

Received August $16^{\text {th }}, 2012$; revised September $20^{\text {th }}, 2012$; accepted October $6^{\text {th }}, 2012$

\begin{abstract}
Background: Accumulating evidence has suggested that cell-free DNA (cf-DNA) enters the circulation following cell apoptosis or necrosis. An increased level of cf-DNA fragments has been found in the blood of mice with drug-induced liver damage. We sought to determine the role of cf-DNA in hepatocellular damage. Methods: Plasma samples were collected from 204 patients with hepatitis. The patients were divided into three groups according to liver pathologic characteristics: with chronic hepatitis $(\mathrm{CH})$ and compensated liver cirrhosis (LC) (the group 1); with decompensated liver cirrhosis (DLC) (the group 2); with liver failure (LF), acute hepatitis (AH) and hepatocellular carcinoma (HCC) (the group 3). The cf-DNA was extracted with the phenol/chloroform/isoamyl alcohol (PCI) method and the plasma cf-DNA was quantified using real-time polymerase chain reaction (rt-PCR) for $\beta$-globin. The cf-DNA copies were converted to $\log _{2}$ values for comparison. Results: Cf-DNA was detected in all the 3 groups. The group 3 had a significantly higher cf-DNA level than the other two groups $(17.70 \pm 1.79, P=0.002)$. The level of plasma cf-DNA was correlated with the baseline aniline transaminase (ALT) and aspertate transaminase (AST) activities $(P<0.005)$. The cf-DNA concentration in patients with cirrhosis was correlated with the model of end-stage liver disease-Na (MELD-Na) score and the ALT and AST activities. Correlation of the cf-DNA level with laboratory parameters, such as bilirubin and international normalized ratio (INR), were found in patients with high cf-DNA levels (cf-DNA > 19.5), or with severe hepatocellular damage $($ ALT $>500 \mathrm{U} / \mathrm{L})$. Conclusion: Plasma cell-free DNA may be a new promising, independent, non-invasive biomarker for hepatocellular damage.
\end{abstract}

Keywords: Hepatocellular Damage; Cell-Free DNA

\section{Introduction}

The World Health Organization reports that cirrhosis and primary liver cancer caused 783,000 and 619,000 death, respectively, in 2002 (WHO, 2003). Most of these deaths in both developing and developed countries are attributed to hepadnavirus infection. Hepadnavirus infection may cause acute hepatitis, chronic hepatitis, cirrhosis, and hepatocellular carcinoma. Liver biopsy has long been used as the gold standard for the clinical evaluation of chronic hepatitis. However, invasion and sampling error make biopsy a flawed benchmark.

Recently noninvasive marker tests such as liver function tests and coagulation tests have been widely adopted to assess the severity of acute and chronic liver injury. The model for endstage liver disease (MELD) score is used to rank patients awaiting liver transplants based on 3 laboratory variations including international normalized ratio (INR), serum creatine and total bilirubin (Kamath, 2007). The MELD-Na score, created as an accurate predictor of survival in patients with advanced liver diseases, provides better prognostic accuracy than the MELD score (Hsu, 2010). However, all the above tests cannot provide specific or direct measurements of the liver

*objectives: None of the authors has any potential financial conflict of interest related to this manuscript.

" Corresponding author. function. For example, elevated serum levels of the baseline aniline transaminase (ALT) and aspertate transaminase (AST) are nonspecific indicators of hepatocellular damage; hyperbilirubinemia may not be detected in the cases of moderate to severe hepatocellular damage; albumin has a long half-life time and cannot immediately reflect changes in hepatic synthesis; the prolonged prothrombin time is not a distinctive feature of liver diseases (Pratt \& Schiff, 2007; Dufour, 2000). Therefore, one easy, direct, specific marker is needed to assist physicians in the diagnosis and treatment of patients with hepatitis.

An elevated level of circulating cell-free DNA (cf-DNA) has been detected in patients under pathologic conditions such as cancer, trauma, stroke, pregnancy, autoimmune disorders, and solid organ transplant (Tokuhisa, 2007; Kamat, 2010; Lam, 2003; Lau, 2002; Holdenrieder, 2006; Lui, 2002). Roth et al. have also found that the cf-DNA level is elevated in the serum of liver failure patients (Roth, 2009). There are two origins of the circulating cf-DNA in patients under pathologic conditions: the DNA fragments enter the blood following cell death; they are actively released by living cells (Van der Vaart, 2007). However, the origin and mechanism of the increased cf-DNA are still uncertain. Liver cell death can be attributed to apoptosis or necrosis or a combination of the two. Apoptosis is a prominent feature of acute and chronic hepatocellular damage. 
Moreover, the cf-DNA clearance mechanism is poorly understood. Emlen et al. have produced evidence suggesting that the liver may be the major organ for the removal of cf-DNA (Emlen, 1978). Another research has reported that circulating DNA has a short half-life time of $16.3 \mathrm{~min}$ in plasma (Lo, 1999). We hypothesized that cf-DNA could be another non-invasive marker of hepatocellular damage. The aim of our research was to evaluate the role of cf-DNA as a biomarker of hepatocellular damage and to investigate the effect of the impaired liver and renal function on the cf-DNA level in plasma.

\section{Materials and Methods}

\section{Plasma Samples}

204 archived plasma samples were obtained from 204 patients on the first day when they visited the First Affiliated Hospital of Medical School of Xi'an Jiaotong University (China). All the patients were diagnosed as having viral, druginduced or unexplained hepatitis without immunologic diseases. According to their pathological characteristics, patients were divided into 3 groups: the group 1 (60) including patients with chronic hepatitis $(\mathrm{CH})$ and compensated liver cirrhosis (LC), the group 2 (66) including patients with decompensated liver cirrhosis (DLC) and the group 3 (78) including patients with liver failure (LF), acute hepatitis (AH), and hepatocellular carcinoma (HCC). Written informed consent was obtained directly from each patient before peripheral blood was collected. Blood samples $(3 \mathrm{ml})$ were drawn into tubes containing ethylenediamine tetra-acetic acid (EDTA). Plasma fractions were separated within 2 hours according to a two-step centrifugation procedure: at $1600 \times \mathrm{g}$ for $10 \mathrm{~min}$ and at $16,000 \times \mathrm{g}$ for $10 \mathrm{~min}$. The plasma fractions were stored at $-80^{\circ} \mathrm{C}$ until further processing.

\section{DNA Extraction from Plasma Samples}

Cell-free DNA was extracted with the golden phenol/chloroform/isoamyl alcohol (PCI) method. $300 \mu$ plasma was mixed with a lysis solution and proteinase $\mathrm{K}$. The mixture was incubated at $56^{\circ} \mathrm{C}$ for $2 \mathrm{~h}$ and then heat denatured at $95^{\circ} \mathrm{C}$ for 10 min. $1200 \mu$ l of phenol: chloroform: isoamyl alcohol (25:24:1) was added to the mixture. The top aqueous layer, after centrifugation at $12,000 \mathrm{rpm}$ for $15 \mathrm{~min}$, was mixed with $100 \%$ ethanol and precipitated at $-20^{\circ} \mathrm{C}$ overnight. The precipitates were washed with $70 \%$ ethanol and dissolved with distilled water. All the cell-free DNA samples were stored at $-20^{\circ} \mathrm{C}$ until quantification.

\section{Quantification of Cell-Free DNA}

Quantification of cell-free DNA ( $\beta$-globin) was performed using real-time polymerase chain reaction (rt-PCR) with SYBR Green I (Applied Biosystem 7500). The forward primer was ACACAACTGTGTTCACTAGC and the reverse primer was CAACTTCATCCACGTTCACC. The thermal cycling protocol was as follows: $95^{\circ} \mathrm{C}$ for $1 \mathrm{~min}$, followed by 40 cycles at $95^{\circ} \mathrm{C}$ for $30 \mathrm{~s}$, at $57^{\circ} \mathrm{C}$ for $20 \mathrm{~s}$ and at $72^{\circ} \mathrm{C}$ for $32 \mathrm{~s}$. A standard curve was created and the DNA concentration, expressed as genome equivalents per milliliter $(\mathrm{GE} / \mathrm{ml})$, was calculated using the following equation:

$$
\mathrm{C}=\mathrm{Q} \times\left(\mathrm{V}_{\mathrm{DNA}} / \mathrm{V}_{\mathrm{PCR}}\right) \times\left(1 / \mathrm{V}_{\mathrm{EXT}}\right)
$$

where $C$ is the target concentration in plasma $(\mathrm{GE} / \mathrm{ml}), Q$ is the target quantity (copies), $\mathrm{V}_{\mathrm{DNA}}$ is the total volume of DNA extraction $(60 \mu \mathrm{l}), \mathrm{V}_{\mathrm{PCR}}$ is the volume of DNA used per PCR reaction $(9.5 \mu \mathrm{l})$, and $\mathrm{V}_{\mathrm{ext}}$ is the volume of plasma used to extract DNA $(300 \mu \mathrm{l})$. All samples were run in triplicate.

\section{Statistical Analysis}

All statistical procedures were performed using SPSS16.0 statistical software. The plasma cf-DNA concentrations of the three hepatitis groups were compared with the nonparametric Mann-Whitney U test and the LSD (least significant difference)-t test. The Kruskal-Wallis H test was used to compare the laboratory parameters among the three groups, and the nonparametric Spearman test was applied to determine the bivariate correlation. In all tests, $P<0.05$ was considered statistically significant.

\section{Results}

Our cohort included 146 patients with HBV infection, 33 with $\mathrm{HCV}$ infection and 25 with unexplained, drug-induced, hepatitis A virus (HAV) or hepatitis E virus (HEV) infection. Table 1 shows the information of the patients, their cf-DNA concentrations and the results of all the laboratory tests, including liver function tests, renal function tests, sodium test, blood routine tests and coagulation tests.

Cell-free DNA was detected in all patients. Cf-DNA concentration mainly ranges from 15 to 20 (Figure 1(a)). Patients with cf-DNA $<15$ were mainly from the group 2 while patients with cf-DNA $>20$ were mainly from the groups 2 and 3 . As shown in Figure 1(b), the highest mean concentration of cf-DNA was observed in the group $3(17.70 \pm 1.79)$, followed by the group 1 $(17.13 \pm 1.12)$ and group $2(16.69 \pm 1.93)(P=0.002)$ with statistic significance. The cf-DNA concentration was found to have no correlation with age, sex, etiology and diagnosis of hepatitis.

The cf-DNA concentration was positively correlated with ALT activity, AST activity and white blood cell (WBC) count $(\mathrm{r}=0.183,0.267$ and 0.156 , respectively; $P=0.009,0.000$ and 0.028 , respectively).

\section{Correlation of cf-DNA with Laboratory Parameters in Cirrhosis Patients}

The MELD score and MELD-Na score of patients with compensated and decompensated cirrhosis, excluding patients with HCC and liver failure, were calculated. The circulating cf-DNA concentration was negatively correlated with the MELD-Na score $(\mathrm{r}=-0.256, P=0.036)$, but showed no correlation with the MELD score $(P>0.05)$. The cf-DNA concentration was also found to be correlated with ALT activity, AST activity and INR $(\mathrm{r}=0.353,0.336$ and -0.282 , respectively and $P=0.001,0.002$ and 0.010, respectively) (Figure 2).

\section{Correlations of cf-DNA with Laboratory Parameters at cf-DNA $>19.5$}

We further included the patients with a high cf-DNA concentration (cf-DNA > 19.5) into the Spearman-test, using 19.5 as the baseline concentration. It was found that the high cf-DNA concentration was significantly correlated with clinical parameters indicating hepatocellular damage and liver function, 
Table 1.

Clinical parameters results and cell free DNA concentration (mean \pm S.D.).

\begin{tabular}{|c|c|c|c|c|}
\hline & $\mathrm{CH}$ and $\mathrm{LC}^{\mathrm{a}}$ & $\mathrm{DLC}^{\mathrm{b}}$ & $\mathrm{LF}, \mathrm{AH}$ and $\mathrm{HCC}^{\mathrm{c}}$ & $P$ \\
\hline Age $(\text { year })^{d}$ & $43.95(17-74)$ & $49.62(18-79)$ & $42.26(5-78)$ & 0.007 \\
\hline Gender $^{\mathrm{e}}$ & $43 / 17$ & $42 / 24$ & $61 / 17$ & 0.156 \\
\hline Cell Free DNA & $17.13 \pm 1.12$ & $16.69 \pm 1.93$ & $17.70 \pm 1.79$ & 0.002 \\
\hline $\operatorname{ALT}(\mathrm{U} / \mathrm{L})$ & $291.9 \pm 441.2$ & $54.3 \pm 47.7$ & $224.1 \pm 428.5$ & 0.000 \\
\hline AST (U/L) & $263.1 \pm 357.6$ & $72.8 \pm 61.5$ & $209.7 \pm 281.0$ & 0.000 \\
\hline $\mathrm{CHOL}(\mathrm{mmol} / \mathrm{L})$ & $3.63 \pm 1.29$ & $2.71 \pm 1.10$ & $2.58 \pm 1.61$ & 0.000 \\
\hline TBIL $(\mu \mathrm{mol} / \mathrm{L})$ & $98.9 \pm 1.2$ & $79.7 \pm 1.4$ & $216.9 \pm 2.0$ & 0.000 \\
\hline DBIL $(\mu \mathrm{mol} / \mathrm{L})$ & $45.7 \pm 58.3$ & $29.8 \pm 57.9$ & $100.3 \pm 93.8$ & 0.000 \\
\hline $\operatorname{ALB}(g / L)$ & $35.7 \pm 4.2$ & $30.1 \pm 5.5$ & $32.6 \pm 6.3$ & 0.000 \\
\hline $\mathrm{PA}(\mathrm{g} / \mathrm{L})$ & $93.7 \pm 77.2$ & $65.6 \pm 49.5$ & $63.3 \pm 72.7$ & 0.007 \\
\hline $\operatorname{CREA}(\mu \mathrm{mol} / \mathrm{L})$ & $76.9 \pm 15.7$ & $94.6 \pm 65.3$ & $94.0 \pm 79.4$ & 0.878 \\
\hline $\mathrm{Na}(\mathrm{mmol} / \mathrm{L})$ & $138.1 \pm 4.0$ & $134.6 \pm 6.7$ & $132.4 \pm 6.7$ & 0.000 \\
\hline $\mathrm{WBC}\left(\times 10^{9} / \mathrm{L}\right)$ & $4.91 \pm 2.69$ & $4.12 \pm 2.63$ & $6.26 \pm 4.57$ & 0.001 \\
\hline NEUT $\left(\times 10^{9} / \mathrm{L}\right)$ & $2.55 \pm 2.14$ & $2.35 \pm 1.92$ & $3.82 \pm 3.00$ & 0.002 \\
\hline PTA (\%) & $83.38 \pm 15.31$ & $67.75 \pm 21.73$ & $67.50 \pm 25.61$ & 0.001 \\
\hline INR & $1.12 \pm 0.13$ & $1.43 \pm 0.61$ & $1.68 \pm 1.04$ & 0.000 \\
\hline
\end{tabular}

Note: ${ }^{\mathrm{C}} \mathrm{CH}$ and LC: chronic hepatitis and liver cirrhosis; ${ }^{\mathrm{b}} \mathrm{DLC}$ : decompensated liver cirrhosis; ${ }^{\mathrm{L}} \mathrm{LF}$, AH and HCC: liver failure, acute hepatitis and hepatocellular carcinoma; ${ }^{\mathrm{d}}$ data are median (range); ${ }^{\mathrm{e}}$ data are Male/Female.

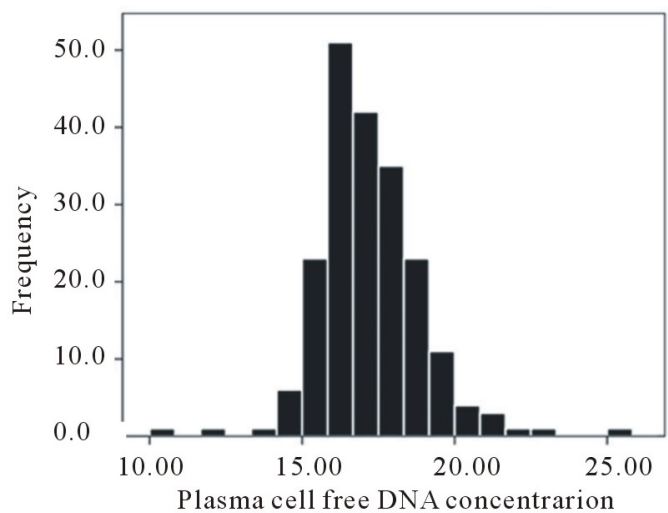

(a)

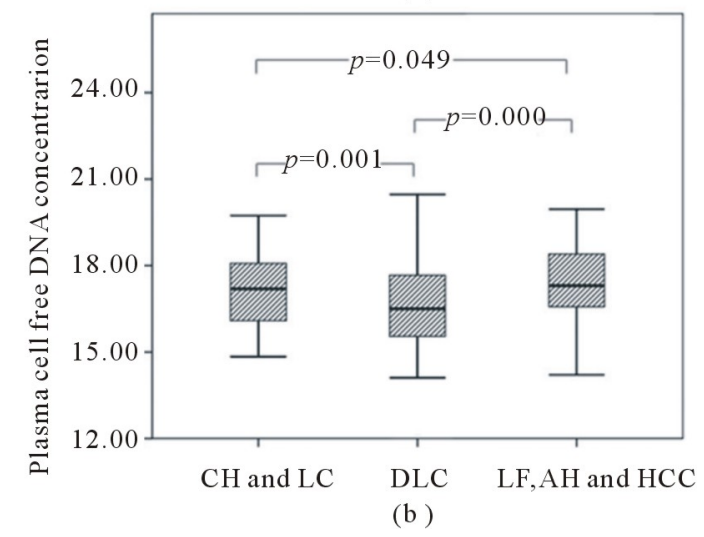

Figure 1.

Plasma cell free DNA concentration mainly range from 15 to 20 (a); Patients in group 3 had the highest plasma cf-DNA concentration $(P=0.002)$. Comparison results of cf-DNA concentration between 2 groups: group $3>\operatorname{group} 1(P=$ $0.049)$, group $3>$ group $2(P=0.000)$, group $1>$ group $2(P$ $=0.002)(\mathrm{b})$. such as ALT, AST, cholesterol (CHOL), total bilirubin (TBIL), direct bilirubin (DBIL) and INR $(r=0.542,0.708,-0.650$, $0.532,0.559$ and 0.564 , respectively; $P=0.037,0.003,0.009$, $0.041,0.030$ and 0.028 , respectively). Next, we examined whether the impaired renal function had any effect on the cf-DNA level. It was found that the cf-DNA level was strongly correlated with the creatine (CREA) ${ }^{3}$ and sodium levels $(\mathrm{r}=$ 0.780 and -0.600 , respectively; $P=0.001$ and 0.030 , respectively) (Figure 3).

\section{Correlations of cf-DNA with Laboratory Parameters at ALT > $500 \mathrm{U} / \mathrm{L}$}

The patients were classified into the ALT $\leq 500 \mathrm{U} / \mathrm{L}$ group (182) and the ALT $>500 \mathrm{U} / \mathrm{L}$ group (19) for the investigation of correlations between individual tests. The ALT $>500 \mathrm{U} / \mathrm{L}$ group had a significantly higher cf-DNA level, compared with the ALT $\leq 500 \mathrm{U} / \mathrm{L}$ group $(\mathrm{P}=0.019)$. At ALT $>500 \mathrm{U} / \mathrm{L}$, the cf-DNA level was significantly correlated with CHOL, TBIL, DBIL, albumin (ALB), pre-albumin (PA), and INR ( $\mathrm{r}=-0.651$, $0.461,0.540,-0.535,-0.615$ and 0.475 , respectively; $P=0.003$, $0.047,0.017,0.018,0.011$ and 0.046, respectively) (Figure 4).

\section{Discussion}

To the best of our knowledge, this is the first large-scale clinical research to determine the role of cf-DNA in hepatocellular damage in hepatitis patients. In the present study, cf-DNA was detected in all hepatitis patients. The patients with LF, AH and HCC had a significantly high level of cf-DNA, when compared with the patients with $\mathrm{CH}$ and LC and the patients with DLC. The concentration of cf-DNA was found to be correlated with the baseline ALT and AST activities, and correlated the MELD-Na score, ALT, AST and INR in patients with cirrhosis. The results suggest that cf-DNA may serve as a biomarker for hepatocellular damage, especially in patients with severe hepatitis. 

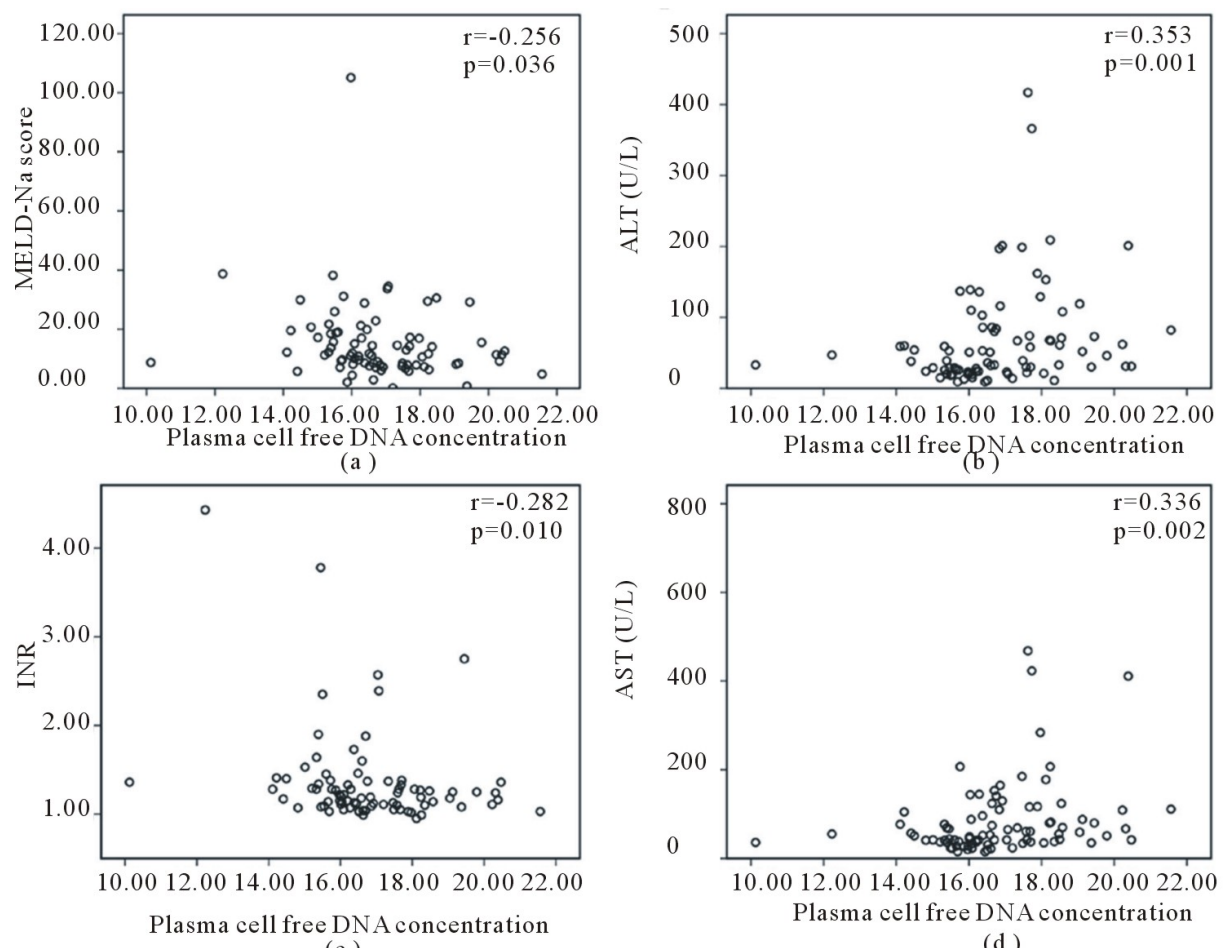

(c)

(d)

Figure 2.

Correlation of cell free DNA concentration with laboratory tests in cirrhosis patients: cf-DNA and MELD-Na score $(\mathrm{r}=-0.256, P=0.036)(\mathrm{a})$; cf-DNA and ALT $(\mathrm{r}=0.353, P=0.001)(\mathrm{b})$; cf-DNA and INR $(\mathrm{r}=-0.282$, $P=0.010)(\mathrm{c})$; cf-DNA and AST $(\mathrm{r}=0.336, P=0.002)(\mathrm{d})$.
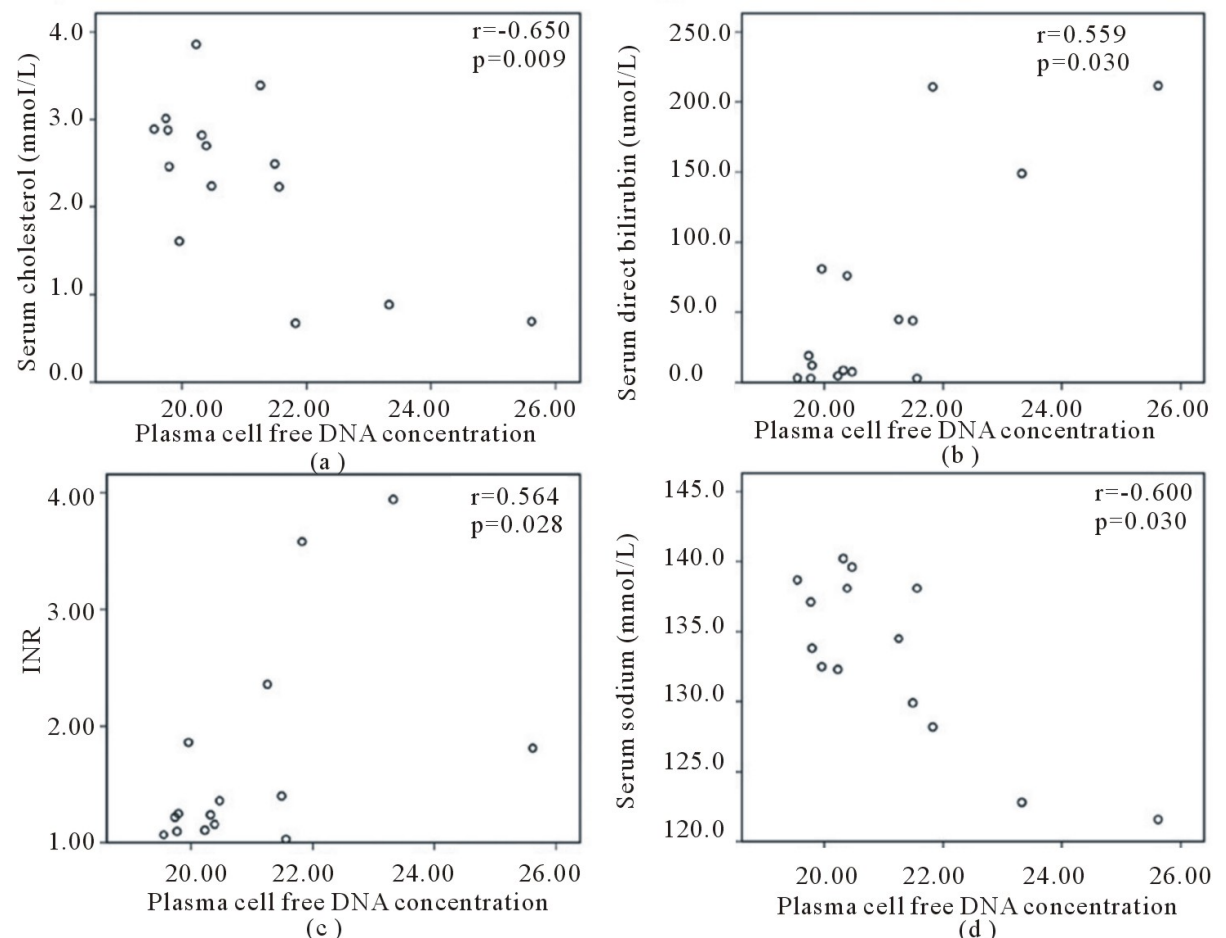

Figure 3.

Correlation of cell free DNA concentration with laboratory tests at cf-DNA $>19.5$ : cf-DNA and serum cholesterol ( $\mathrm{r}=-0.650, P=0.009)(\mathrm{a})$; cf-DNA and serum DBIL $(\mathrm{r}=0.559, P=0.030)(\mathrm{b})$; cf-DNA and INR ( $\mathrm{r}$ $=0.564, P=0.028)(\mathrm{c})$; cf-DNA and AST $(\mathrm{r}=-0.600, P=0.030)(\mathrm{d})$. 

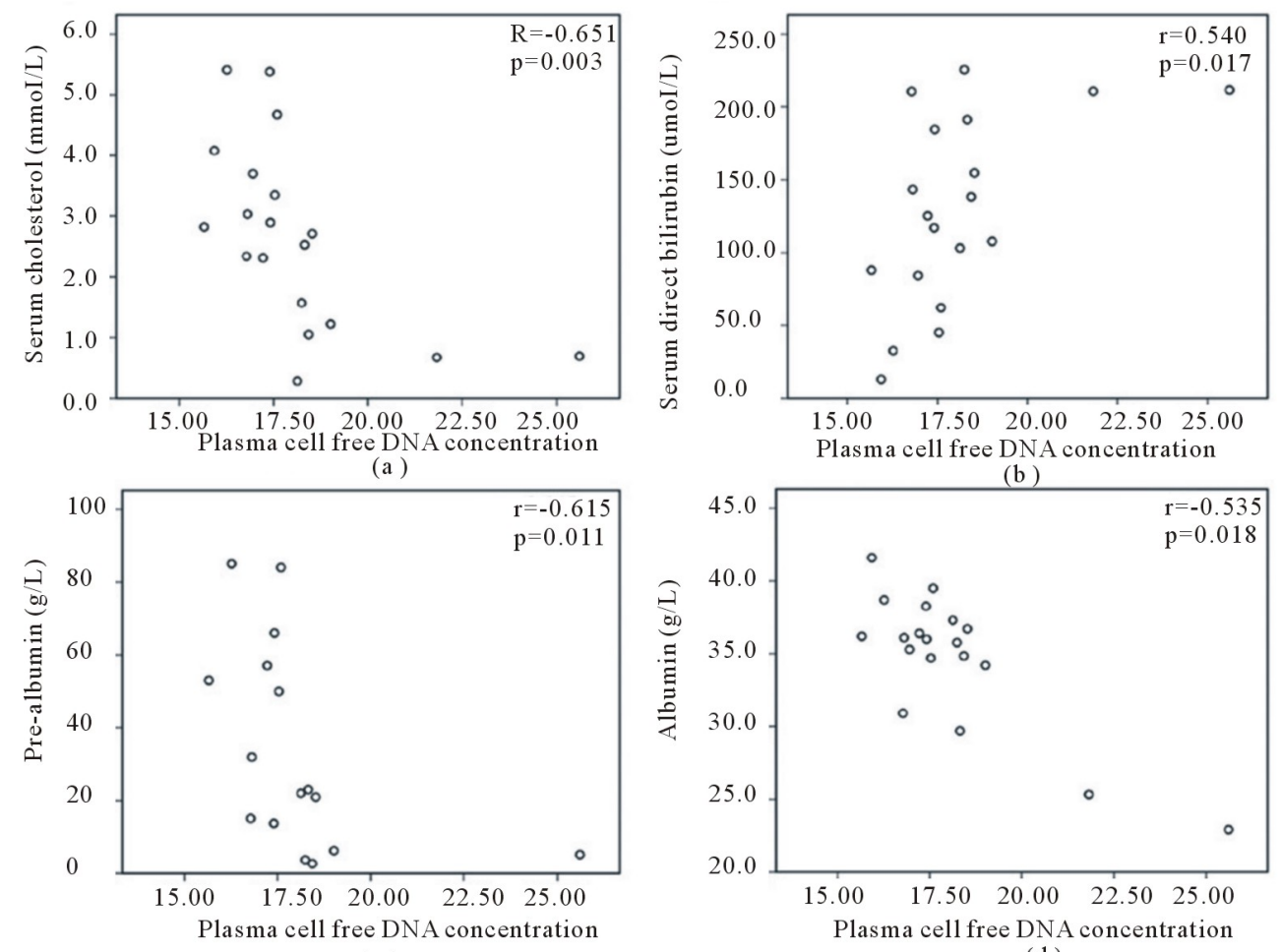

(c)

(d)

Figure 4.

Correlation of cell free DNA concentration with laboratory tests at ALT $>500 \mathrm{U} / \mathrm{L}$ : cf-DNA and serum cholesterol $(\mathrm{r}=-0.651, P=0.003)(\mathrm{a})$; cf-DNA and serum DBIL $(\mathrm{r}=0.540, P=0.017)(\mathrm{b})$; cf-DNA and pre-albumin $(\mathrm{r}=$ $-0.615, P=0.011)(\mathrm{c})$; cf-DNA and albumin $(\mathrm{r}=-0.535, P=0.018)(\mathrm{d})$.

The elevated cf-DNA level may reflect the disturbance of equilibrium between the release and clearance of circulating cf-DNA. The origin of cf-DNA has been studied for approximately 30 years; however, the underlying mechanism is still unclear. Sabine Jahr et al. have detected circulating cf-DNA in the plasma of cancer patients and identified it as a hallmark of necrosis and apoptosis (Jahr, 2001). Philippe Anker et al. have corroborated the spontaneous release of DNA by lymphocytes in vitro (Anker, 1975). Our results revealed a significant elevation of the cf-DNA concentration in patients with severe heaptocellular damage and an association between cf-DNA and WBC. Probably, cell death and inflammation are both the origins of cf-DNA in patients with hepatitis. Emlen et al. have found that the liver is the major organ for removal of circulating ssDNA (Emlen, 1978). Botezatu et al. have detected malespecific DNA sequences in the urine of females who had been transfused with male blood (Botezatu, 2000). Maybe impaired liver or kidney function is another explanation for the elevation of the cf-DNA concentration.

The key finding of this study is that although not all individuals showed an elevated cf-DNA concentration, the mean cf-DNA concentration was significantly elevated in the group 3 patients with severe hepatocellular damage and poor hepatic function, when compared with those in the other two groups. This study possessed potential confounding factors that cannot be ruled out. For example, some of the patients were complicated with upper gastrointestinal tract bleeding, or ascites. We could not match all the confounding factors in our study groups.

To date, ALT activity, AST activity and bilirubin have been generally used by clinicians to assess the severity of liver injury. Aminotransferases and bilirubin are sensitive indicators of hepatocellular damage. The highest elevations of the aminotransferases level occur in disorders associated with extensive hepatocellular damage. In our study, circulating cf-DNA concentrations were found to be correlated with the baseline ALT and AST activities. The liver is the major site of synthesis of cholesterol, protein and blood coagulation factors. Our results show that cf-DNA increased with the severity of the impaired liver function. Interestingly, cf-DNA was found to be correlated with aminotransferases when patients with cirrhosis were considered as a whole, but to show no correlation with aminotransferases in patients with chronic hepatitis. These data support the hypothesis that the mechanism underlying the elevation of the cf-DNA level in the plasma is not only associated with hepatocellular damage but also with impaired liver function.

Hepatorenal syndrome (HRS) is a fatal complication of decompensated cirrhosis. HRS may be manifested as impaired renal function, ascites and edema. Sodium retention plays a fundamental role in the formation of ascites and edema and is the first manifestation of renal impairment in patients with cirrhosis. Creatinine is a marker for decreased renal perfusion. Based on the relations between cf-DNA and serum sodium and CREA at cf-DNA $>19.5$, we predicted that kidney might play a role in the elevation of the circulating cf-DNA. We also established the relationship between cf-DNA and WBC, which is in agreement with the finding of a previous study [6].

Cf-DNA originates from cell death; however, little hepatic cells were reserved in patients with cirrhosis. Based on this 
knowledge, we found a moderately negative correlation between cf-DNA and MELD-Na score. MELD-Na score has been introduced as a predictor of mortality and can provide better prognostic accuracy than MELD-score (Kamath, 2007). Therefore, Cf-DNA can be selected as non-invasive assessment marker for survival and prognosis of patients with hepatic diseases.

Lee et al. found that most cf-DNA in the serum samples was generated during the process of clotting in the original collection tubes (Lee, 2001). Fong L. et al. performed a comparative study of 7 cf-DNA isolation methods, and their results showed that PCI was a highly efficient method for cf-DNA isolation, compared with QIAamp DNA blood kit (Fong, 2009). Jung et al. described that plasma cf-DNA did not change after blood samples were stored at room temperature for $8 \mathrm{~h}$ or at $4^{\circ} \mathrm{C}$ for $24 \mathrm{~h}$ before being processed (Jung, 2003). Based on the above findings, in this study, blood samples were collected into EDTA-tubes (Lam, 2004) to exclude contaminants from lyses cells during clotting and residual cells were removed from plasma within $2 \mathrm{hrs}$ after blood collection using a two-step centrifugation method.

In conclusion, cf-DNA can immediately provide easy and direct measurement of hepatocellular damage. The plasma cellfree DNA concentration may be a new promising non-invasive independent biomarker for hepatocellular damage. Impaired liver and kidney may play a role in the elevation of the plasma cf-DNA level. These findings may provide valuable information for further studies on the mechanism, origin and kinetics of the circulating cf-DNA associated with hepatocellular damage.

\section{Acknowledgements}

Grant support was provided by the Major National Science and Technology Projects for Infectious Diseases (11th Five Year, China) (Project Code 2008ZX10002-007).

\section{REFERENCES}

Anker, P., Stroun, M., \& Maurice, P. A. (1975). Spontaneous release of DNA by human blood lymphocytes as shown in an in vitro system. Cancer Research, 35, 2375-2382.

Botezatu, I., Serdyuk, O., Potapova, G., Shelepov, V., Alechina, R., Molyaka, Y. et al. (2000). Genetic analysis of DNA excreted in urine: A new approach for detecting specific genomic DNA sequences from cells dying in an organism. Clinical Chemistry, 46, 1078-1084.

Dufour, D. R., Lott, J. A., Nolte, F. S., Gretch, D. R., Koff, R. S., \& Seeff, L. B. (2000). Diagnosis and monitoring of hepatic injury. II. Recommendations for use of laboratory tests in screening, diagnosis, and monitoring. Clinical Chemistry, 46, 2050-2068.

Emlen, W., \& Mannik, M. (1978). Kinetics and mechanisms for removal of circulating single-stranded DNA in mice. Journal of Experimental Medicine, 147, 684-699. doi:10.1084/jem.147.3.684

Fong, S. L., Zhang, J. T., Lim, C. K., Eu, K. W., \& Liu, Y. (2009). Comparison of 7 methods for extracting cell-free DNA from serum samples of colorectal cancer patients. Clinical Chemistry, 55, 587589. doi:10.1373/clinchem.2008.110122

Holdenrieder, S., Eichhorn, P., Beuers, U., Samtleben, W., Schoenermarck, U., Zachoval, R. et al. (2006). Nucleosomal DNA fragments in autoimmune diseases. Annals of the New York Academy of Sciences, 1075, 318-327. doi:10.1196/annals.1368.043

Hsu, C. Y., Lin, H. C., Huang, Y. H., Su, C. W., Lee, F. Y., Huo, T. I. et al. (2010). Comparison of the model for end-stage liver disease (MELD), MELD-Na and MELDNa for outcome prediction in patients with acute decompensated hepatitis. Digestive and Liver Disease, 42, 137-142. doi:10.1016/j.dld.2009.06.004

Jahr, S., Hentze, H., Englisch, S., Hardt, D., Fackelmayer, F. O., Hesch, R. D., et al. (2001). DNA fragments in the blood plasma of cancer patients: Quantitations and evidence for their origin from apoptotic and necrotic cells. Cancer Research, 61, 1659-1665.

Jung, M., Klotzek, S., Lewandowski, M., Fleischhacker, M., \& Jung K. (2003). Changes in concentration of DNA in serum and plasma during storage of blood samples. Clinical Chemistry, 49, 1028-1029. doi: $10.1373 / 49.6 .1028$

Kamat, A. A., Baldwin, M., Urbauer, D., Dang, D., Han, L. Y., Godwin, A. et al. (2010). Plasma cell-free DNA in ovarian cancer: An independent prognostic biomarker. Cancer, 116, 1918-1925. doi:10.1002/cncr.24997

Kamath, P. S., \& Kim, W. R. (2007). The model for end-stage liver disease (MELD). Hepatology, 45, 797-805. doi:10.1002/hep.21563

Lam, N. Y., Rainer, T. H., Chan, L. Y., Joynt, G. M., \& Lo, Y. M. (2003). Time course of early and late changes in plasma DNA in trauma patients. Clinical Chemistry, 49, 1286-1291. doi: $10.1373 / 49.8 .1286$

Lam, N. Y., Rainer, T. H., Chiu, R. W., \& Lo, Y. M. (2004). EDTA is a better anticoagulant than heparin or citrate for delayed blood processing for plasma DNA analysis. Clinical Chemistry, 50, 256-257. doi:10.1373/clinchem.2003.026013

Lau, T. W., Leung, T. N., Chan, L. Y., Lau, T. K., Chan, K. C., Tam, W. H. et al. (2002). Fetal DNA clearance from maternal plasma is impaired in preeclampsia. Clinical Chemistry, 48, 2141-2146.

Lee, T. H., Montalvo, L., Chrebtow, V., \& Busch, M. P. (2001). Quantitation of genomic DNA in plasma and serum samples: Higher concentrations of genomic DNA found in serum than in plasma. Transfusion, 41, 276-282. doi:10.1046/j.1537-2995.2001.41020276.x

Lo, Y. M., Zhang, J., Leung, T. N., Lau, T. K., Chang, A. M., \& Hjelm, N. M. (1999). Rapid clearance of fetal DNA from maternal plasma. The American journal of Human Genetics, 64, 218-224. doi: $10.1086 / 302205$

Lui, Y. Y., Chik, K. W., Chiu, R.W., Ho, C. Y., Lam, C. W., \& Lo, Y. M. (2002). Predominant hematopoietic origin of cell-free DNA in plasma and serum after sex-mismatched bone marrow transplantation. Clinical Chemistry, 48, 421-427.

Pratt, D. S., \&Kaplan, M. M. (2007). Laboratory tests. In E. R. Schiff, (Ed.), Schiff's diseases of the liver (10th ed., pp. 19-54). Hoboken, NJ: Wiley-Blackwell.

Roth, G. A., Lubsczyk, B. A., Pilz, J., Faybik, P., Hetz, H., \& Krenn, C. G. (2009). Nucleosome serum levels in acute hepatic failure and MARS treatment. Transplant Proceedings, 41, 4207-4210. doi:10.1016/j.transproceed.2009.08.073

Tokuhisa, Y., Iizuka, N., Sakaida, I., Moribe, T., Fujita, N., Miura, T. et al. (2007). Circulating cell-free DNA as a predictive marker for distant metastasis of hepatitis $\mathrm{C}$ virus-related hepatocellular carcinoma. British Journal of Cancer, 97, 1399-1403. doi:10.1038/sj.bjc.6604034

van der Vaart, M., \& Pretorius, P. J. (2007). The origin of circulating free DNA. Clinical Chemistry, 53, 2215. doi:10.1373/clinchem.2007.092734

World Health Organization (2003). The world health report 2003Shaping the future. URL (last checked 16 August 2012). http://www.who.int/whr/2003/en/ 


\section{Abbreviations}

cf-DNA: cell-free DNA

$\mathrm{CH}$ : chronic hepatitis

LC: compensated liver cirrhosis

DLC: decompensated liver cirrhosis
LF: liver failure

AH: acute hepatitis

HCC: hepatocellular carcinoma

CREA: creatine 